\title{
Pelatihan Pengolahan Produk Berbahan Dasar Rumput Laut Di Kelurahan Sarae
}

\author{
${ }^{1}$ Sri Ernawati, ${ }^{2}$ M. Yususf, ${ }^{3}$ Rujalil, ${ }^{4}$ Katarina \\ 12 Dosen Program study Manajemen, Sekolah Tinggi Ilmu Ekonomi Bima \\ ${ }^{34}$ Mahasiswa Program study Manajemen, Sekolah Tinggi Ilmu Ekonomi Bima \\ Email: sriernawati.stiebima@gmail.com, yusuf.stiebima@gmail.com
}

\begin{abstract}
This community service activity is the provision of training on processing seaweed-based products. The participants of this training activity are mothers of productive age and teenagers. The purpose of this training on processing seaweed-based products is that the community is able to process seaweed into high-value innovation products so that they can help the household economy of the trainees. The training was conducted for 1 day in the Sarae Village office hall. The results of the activity showed that the participants understood the training provided. The success is shown by the positive response from the participants, by being directly involved in the process of processing seaweed into lunkhead and rengginang as well as the packaging process of processed products.
\end{abstract}

Keywords : Training, Seaweed Processing

\begin{abstract}
Abstrak
Kegiatan pengabdian kepada masyarakat ini merupakan pemberian pelatihan tentang pengolahan produk berbahan dasar rumput laut. Peserta kegiatan pelatihan ini adalah ibuibu usia produktif dan remaja. Tujuan pelatihan pengolahan produk berbahan dasar rumput laut ini adalah masyarakat mampu mengolah rumput laut menjadi produk inovasi yang bernilai tinggi sehingga dapat membantu perekonomian rumah tangga peserta pelatihan. Pelatihan dilakukan 1 hari di Aula kantor Kelurahan sarae. Hasil kegiatan menunjukkan bahwa peserta memahami pelatihan yang diberikan. Keberhasilan ditunjukkan dengan adanya respon positif dari peserta, dengan terlibat langsung saat proses pengolah rumput laut menjadi dodol dan rengginang serta proses pengemasan produk olahan.
\end{abstract}

Kata Kunci: Pelatihan, Pengolahan Rumput Laut

\section{Pendahuluan}

Rumput laut atau alga telah lama menjadi salah satu produk yang banyak dikonsumsi oleh masyarakat dunia. Bangsa-bangsa di Asia Timur (Jepang dan China) dan Kekaisaran Romawi telah menggunakan tumbuhan laut ini sebagai bahan pangan dan obat-obatan sejak ribuan tahun yang lalu. Sementara di Britania Raya, rumput laut telah dikenal paling tidak sejak tahun 1200 M (Rose, 2016). Di Indonesia sendiri, rumput laut telah lama dikonsumsi oleh masyarakat, terutama di daerah pesisir (Waryono, 2001). Pada umumnya, pemanfaatan rumput laut pada masa itu adalah untuk dimakan atau dikonsumsi langsung. 
Saat ini, dengan kemajuan ilmu pengetahuan dan teknologi, pemanfaatan rumput laut sudah sangat beragam, baik itu untuk produk pangan maupun non pangan. Secara garis besar, produk turunan rumput laut dapat dikelompokkan menjadi 5P, yaitu Pangan, Pakan, Pupuk, Produk Kosmetik, dan Produk Farmasi (KKP, 2016). Sejumlah penelitian juga menyebutkan bahwa rumput laut dapat digunakan sebagai bahan dasar dalam pembuatan bahan bakar atau biofuel (Wiratmaja et al, 2011).

Dengan begitu luasnya penggunaan rumput laut, tidak mengherankan bila komoditas ini menjadi salah satu produk penting dalam perdagangan internasional. Pada tahun 2016, sekitar 1 juta ton produk rumput laut diekspor dengan nilai lebih dari USD 4 milyar atau dengan kurs Rp14.000/ USD, setara Rp. 56 triliun. Sementara itu, tercatat lebih dari 100 negara di dunia menjadi pengimpor komoditas ini (FAO, 2018). Kondisi ini harus dimanfaatkan oleh Indonesia, yang memiliki kondisi geografis yang menguntungkan untuk pertumbuhan rumput laut.

Kegiatan pelatihan yang dilakukan adalah pengembangan teknologi pengolahan rumput laut menjadi berbagai jenis olahan yang berbasis rumput laut. Perkembangan teknologi pengolahan rumput laut sudah berkembang pesat di Indonesia. Banyak masyarakat pesisir yang sudah beralih menjadi pengusaha produk olahan rumput laut (Wonggo, 2010).

\section{Metode Pengabdian}

\section{Metode Kegiatan}

Kegiatan pengabdian kepada masyarakat dilaksanakan di Kelurahan Sarae Kota Bima dengan melibatkan ibu- ibu usia produktif, remaja dan anggota kelompok KKN STIE Bima. Kegiatan dilaksanakan dalam tiga tahap kegiatan, yaitu: 1) Melakukan pendekatan masalah yang dihadapi oleh masyarakat kelurahan sarae dengan melakukan wawancara kepada kepala kelurahan, Star kelurahan dan masyarakat kelurahan sarae. 2) Melakukan pelatihan pembuatan Dodol Rumput laut dan renggianag Rumput laut kepada ibu-ibu usia produktif dan remaja yang mau menjadi wirausaha di Kelurahan Sarae. 3) Melakukan pembuatan kemasan Dodol Rumput laut dan renggianag Rumput laut.

2. Tempat Kegiatan

Kegiatan pelatihan Pengolaha produk berbahan dasar rumput laut dilakukan di Aula Kantor Kelurahan sarae

3. Proses Kegiatan

Kegiatan dilakukan 10 September 2020

\section{Waktu pelaksanaan kegiatan pelatihan}

\begin{tabular}{|l|l|l|l|}
\hline No & kegiatan & Penangung jawab & $\begin{array}{l}\text { Alokasi } \\
\text { waktu }\end{array}$ \\
\hline 1 & Pembuatan Dodol Rumput laut & Katarina & 4 Jam \\
\hline 2 & $\begin{array}{l}\text { Pembuatan Rengginang } \\
\text { Rumput Laut }\end{array}$ & $\begin{array}{l}\text { Yiyin Juhriatun dan Suci } \\
\text { Nurlita }\end{array}$ & Jam \\
\hline
\end{tabular}

\section{Hasil dan Pembahasan}

1. Pelatihan Pembuatan dodol dan rengginang Rumput Laut

Kegiatan pelatihan pembuatan dodol dan rengginang rumput laut dilaksanakan selama satu hari yang bertempat di Aula Kelurahan sarae. Jumlah peserta yang mengikuti pelatihan pembuatan dodol rumput laut adalah 15 orang. 
Acara pelatihan pengolahan rumput laut dibuka oleh Ketua Kelompok KKN STIE BIma. Banyak yang antusian dan menyambut baik kegiatan pelatihan ini, karena selama ini rumput laut hanya dijadikan sebagai urap saja di masyarakat Keluraha Sarae, belum ada yang mengelolanya menjadi produk inovasi yang mempunyai nilai jual yang tinggi. Kegiatan pelatihan pembuatan dodol dan rengginang rumput laut berjalan dengan baik. Ibu-ibu dan remaja antusias dalam mengikuti kegiatan pelatihan. Kegiatan pelatihan diawali dengan pemaparan sekilas tentang nilai ekonomis rumput laut. Kegiatan selanjutnya adalah menjelaskan tentang jenis-jenis olahan rumput laut yang memiliki nilai ekonomis tinggi. Pelatihan pembuatan dodol dan rengginang rumput laut melibatkan beberapa anggota kelompok dalam membantu melakukan demonstrasi pembuatan dodol dan rengginang rumput laut mulai dari persiapan alat dan bahan hingga proses pembuatan dodol dan rengginang rumput laut.

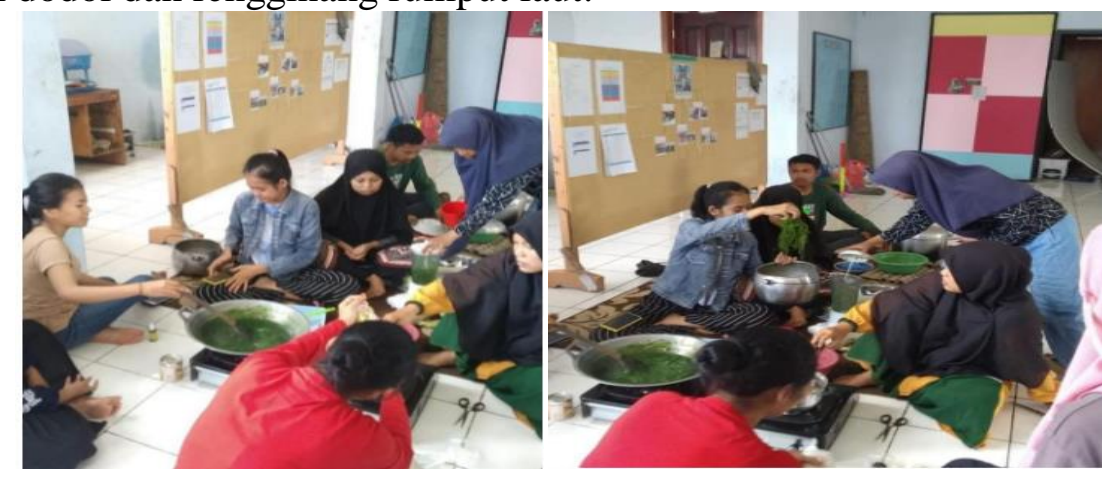

Gambar 1. kegiatan pelatihan pembuatan Dodol dan rengginang Rumput Laut

2. Pelatihan Pembuatan kemasan dodol dan rengginang rumput laut

Secara umum fungsi kemasan adalah untuk melindungi dan mengawetkan produk, seperti melindungi dari sinar ultraviolet, panas, kelembaban udara, oksigen, benturan, kontaminasi dari kotoran dan mikroba yang dapat merusak dan menurunkan mutu produk. Kemasan identitas produk, dalam hal ini kemasan dapat digunakan sebagai alat komunikasi dan informasi kepada konsumen melalui label yang terdapat pada kemasan. Dalam pelatihan ini dilakukan juga pelatihan pengemasan produk dodol dan rengginang rumput laut agar produk yang dihasilkan bisa bersaing dipasaran. 


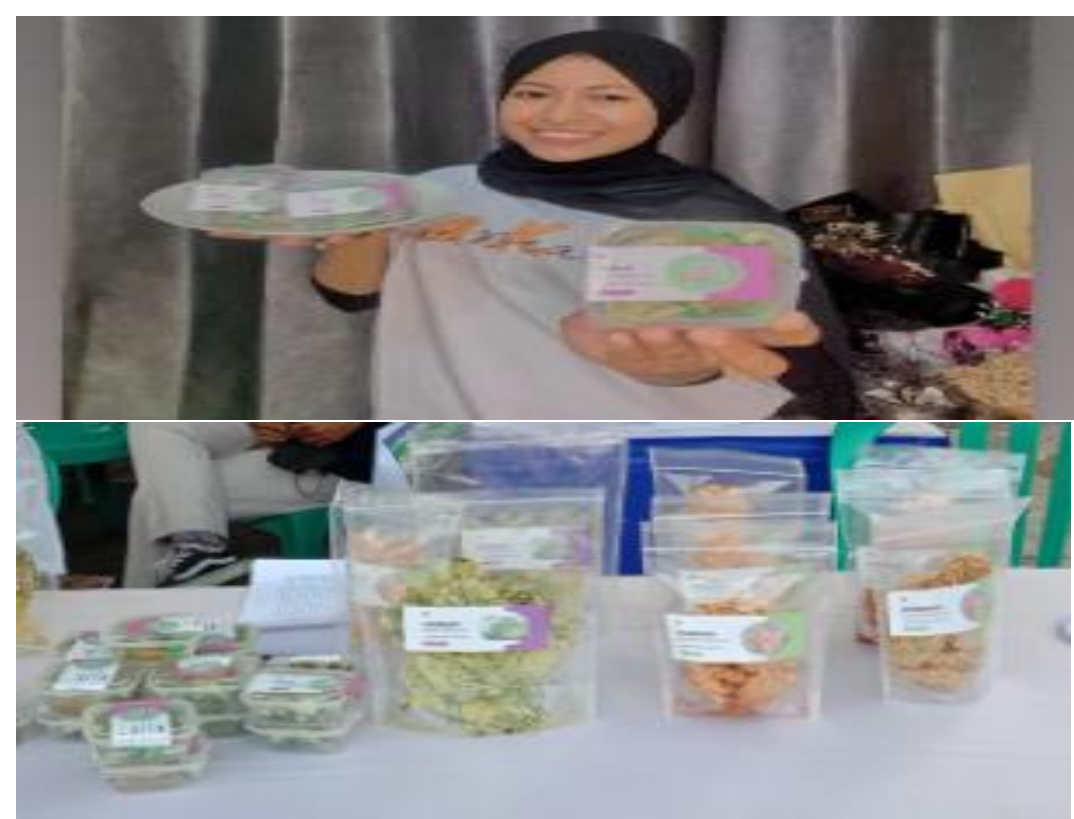

Gambar 2. Produk dodol dan Rengginang rumput laut yang sudah dalam kemasan

\section{Simpulan}

Kegiatan pelatihan pembuatan dodol dan rengginang rumput laut telah tercapai dan berhasil, yaitu memberikan informasi kepada ibu-ibudan remaja kelurahan Sarae tentang pengolahan rumput laut mengenai cara mengolah rumput laut menjadi dodol dan rengginang rumput laut yang dapat memberikan nilai tambah bagi masyarakat sekitar. Hasil kegiatan menunjukkan bahwa peserta memahami materi yang diberikan. Keberhasilan ditunjukkan dengan adanya respon positif dari peserta, dengan mengajukan berbagai pertanyaan dan tanggapan terkait pembuatan dodol dan rengginang rumput laut.

\section{Daftar Pustaka}

FAO. (2018). The Global Status of Seaweed Production, Trade and Utilization Vol. 124. Roma

KKP. (2016). Rumput Laut dan Pemanfaatannya. Jakarta.

Rose, Craig. (2016). The History of Seaweed and The Ways to Achieve Seaweed Benefits. https://www.seaweedandco.com/seaweed-supply-history/. Diakses pada tanggal 13 September 2019

Waryono, Tarsoen. (2001). Biogeografi Alga Makro (Rumput Laut) Di Kawasan Pesisir Indonesia. Seminar Ikatan Geografi Indonesia (IGI). Malang

Wiratmaja I Gede, I Gusti Bagus Wijaya Kusuma, dan I Nyoman Suprapta Winaya. (2011). Pembuatan Etanol Generasi Kedua Dengan Memanfaatkan Limbah Rumput Laut Eucheuma Cottonii Sebagai Bahan Baku. Jurnal Ilmiah Teknik Mesin Cakram Vol. 5 No.1. April 2011 (7584)

Wonggo, D. Penerimaan Konsumen terhadap Selai Rumput Laut. Jurnal Perikanan dan Kelautan Vol. VI (1); 51-53. 